\title{
STUDI KASUS SELF ESTEEM PADA REMAJA YANG ORANG TUANYA BROKEN HOME DI SMP DHARMA PATRA P. BRANDAN
}

\author{
Dewi Afrina $^{(1)}$, Nurul Hasanah M.Si ${ }^{(2)}$ \\ Sekolah Tinggi Keguruan dan Ilmu Pendidikan ${ }^{(1)}$
}

\begin{abstract}
ABSTRAK
Harga diri (self-esteem) merupakan bagian penting yaitu salah satu masalah dalam kehidupan yang dianggap paling berat adalah masalah yang terjadi dalam keluarga. Remaja ini mempunyai harga diri yang tinggi karena akan bisa meningkatkan prestasi, memiliki kepuasan terhadap aktifitas yang dilakukan, berani menghadapi tantangan dalam hidup. Kondisi ini, menimbulkan dampak yang sangat besar bagi remaja yang dalam proses perkembangannya merupakan saat-saat pembentukan karakter dan kepribadian, terutama untuk kehidupannya di masa yang akan datang. Tujuan dari penelitian ini adalah untuk mengetahui bagaimana gambaran studi kasus self esteem pada remaja yang orang tuanya Broken home serta mengetahui faktor-faktor apa saja yang mempengaruhi pencapaian studi kasus self esteem pada remaja yang orang tuanya broken home.Dalam penelitian ini, peneliti menggunakan metode kualitatif berbentuk studi kasus.Subjek yang digunakan dalam penelitian ini adalah remaja laki-laki berusia 14 tahun dan mengalami broken home sebanyak satu orang.Berdasarkan hasil penelitian diketahui bahwa subjek memilikiRemaja yang memiliki harga diri tinggi merupakan sebagai perasaan yang positif terhadap diri sendiri, termasuk cenderung lebih efektif, aktif dan asertif dalam menyesuaikan diri dengan tuntutan lingkungan.Hal ini juga didukung oleh faktor-faktordari dalam diri dan dari luar diri subjek yang mempengaruhi subjek untuk menjadi seorang yangmempunyai self esteem. Faktor-faktor dari luar diri subjek antara lain hubungan sosial yang baik antara subjek dengan orangtua dan lingkungan sekitarnya, mendapatkan dukungan yang positif dari orang-orang disekitarnya, sedangkan faktor dari dalam diri subjek yaitu memiliki perasaan dicintai dan mampu untuk mencintai orang lain, menjalin hubungan baru, dan mampu berempati.Subjek juga memiliki keyakinan dan harapan yang besarakan kehidupannya di masa yang akan datang, sehingga mampu bangkit dari kondisi sulit dan pengalaman emosional negatif yang dialaminya.
\end{abstract}

Kata Kunci : Studi Kasus, Self Esteem, Broken Home 


\section{PENDAHULUAN}

\section{A. Latar belakang masalah}

Tak ada satu pun orang yang mau menjadi korban broken home. Broken home adalah kurangnya perhatian dari keluarga atau kurangnya kasih sayang dari orang tua sehingga membuat mental seorang remaja menjadi frustasi, brutal dan susah diatur. Broken home sangat berpengaruh besar pada mental seorang pelajar hal inilah yang mengakibatkan seorang pelajar tidak mempunyai minat untuk berprestasi.

Jika remaja pada kondisi seperti ini "broken home" dimana orang tua mereka tidak lagi menjadi panutan bagi dirinya maka akan berdampak besar pada perkembangan dirinya. Dampak psikis yang dialami oleh remaja yang mengalami broken home, remaja menjadi lebih pendiam, pemalu, bahkan despresi berkepanjangan. Jika remaja berada di lingkungan pergaulan yang negatif, karena keadaannya labil maka tidak menutup kemungkinan remaja akan tercebur dalam lembah pergaulan yang tidak baik. Salah satunya di dalam broken home yaitu "perceraian", dalam perceraian yang membuat anak atau remaja yang frustasi.

Perceraian adalah solusi yang menyakitkan untuk orang tua dan juga anak meskipun ia tidak terlibat dalam konflik. Setelah perceraian orang tua akan merasa lega karena tidak lagi berkonflik namun lihat kondisi anak, apakah ia baik-baik saja ? Tentu saja tidak sebab dalam hati remaja ia pasti mendambakan kedua orang tuanya tinggal bersama, namun kenyataannya ia harus menghabiskan harinya bersama salah satu orang tua.
Rasa kecewa, kehilangan, sedih dan tidak aman akan dirasakan remaja ketika perceraian itu terjadi. Orang tua menganggap itu hanyalah masalah waktu dimana anak atau remajanya nantinya akan terbiasa dengan pola dan kebiasaan hidup yang baru.beberapa remaja dapat beraaptasi dengan kondisi baru dengan cepat, namun banyak juga yang merasa sulit bahkan setelah bertahun-tahun perceraian itu terjadi. Jika hal itu dibiarkan, maka akan berpengaruh pada masa perkembangan selanjutnya, bahkan hingga dewasa.

Self Esteem atau harga diri adalah sesuatu yang lebih mendasar dari pada yang terkait dengan naik turunnya perubahan situasi. Bagi orang-orang dengan harga diri yang baik, naik turun perasaan mereka tentang diri mereka sendiri dapat menyebabkan fluktuasi sementara, tetapi itu hanya sampai batas waktu tertentu saja. Sebaliknya, bagi orang-orang yang orang tuanya boken home harga diri atau self esteem, pasang surut ini secara drastis mempengaruhi cara mereka memandang diri mereka.

Ini dapat dilihat dari kutipan:

"Yang membuat saya kecewa, kenapa orang tua saya bisa bercerai dan tidak akur".

Self esteem bukan merupakan bawaan yang telah dimiliki seorang sejak lahir tetapi merupakan suatu komponen kepribadian yang berkembang semenjak awal kehidupan anak. Orang tua memiliki peran yang penting dalam pembentukan self esteem, orang tua yang dijadikan model atau contoh pertama dari proses imitasi anak, ia akan menilai dirinya sebagaimana orang tuanya menilai dirinya. Sebaliknya, jika orang tua salah menjadikan model atau contoh, maka bisa jadi ia atau anak 
akan terjerumus apa yang dilakukan orang tuanya.

\begin{abstract}
Mereka yang memiliki harga-diri (selfesteem) rendah diduga memiliki kecenderungan menjadi rentan terhadap depresi, penggunaan narkoba, dan dekat dengan kekerasan. Harga-diri (self-esteem)yang tinggi membantu meningkatkan inisiatif, resiliensi dan perasaan puas pada diri seseorang. Seseorang dengan harga-diri (selfesteem) tinggi dikatakan memiliki resiliensi yang tinggi, yaitu memiliki kemampuan untuk bangkit kembali, dengan cara mengatasi tekanan yang dialami. Namun demikian, seseorang dengan harga-diri (self-esteem) tinggi bisa saja suatu saat mengalami kegagalan atau kekecewaan yang membuat harga-diri (self-esteem) mereka menurun. Kondisi inilah yang dikenal sebagai hargadiri (self-esteem) yang terancam. Pada kondisi tersebut harga-diri (self-esteem) dapat mengalami penurunan.Situasi dimana seseorang berupaya untuk mempertahankan harga-diri (selfesteem) ini dikenal dengan selfesteem maintenance. Mereka yang merasa hargadirinya (self-esteem) terancam, akan memandang kesuksesan orang lain sebagai sesuatu yang mengancam keberadaan atau keberhargaan diri mereka. Perasaan terancam ini akan menimbulkan reaksi untuk 'menjatuhkan' orang lain,apakah dengan memandang rendah orang lain atau bahkan dengan menggunakan kekerasan.
\end{abstract}

Harga diri yang orang tuanya broken home dengan Harga Diri yang yang orang tuanya tidak broken home, pada saat iniuntuk menentukan bagaimana perasaan mereka tentang diri mereka. Mereka membutuhkan pengalaman eksternal yang positif misalnya, pujian dari teman dan orang orang disekeliling mereka untuk melawan perasaan negatif dan pikiran yang terus-menerus mengganggu mereka. Biasanya perasaan yang baik hanya bersifat sementara.

Berdasarkan uraian diatas, masalah self esteem pada anak remaja yang orang tuanya broken home perlu dibimbing yang benar benar supaya anak tersebut tidak akan melakukan apa yang sudah dilakukan salah satu orang tuanya. Penulis berniat melakukan sebuah penelitian yang berjudul "Studi Kasus Self Esteem Pada Anak Remaja Yang Orang Tuanya Broken Home Di SMP Dharma Patra P.Brandan"

\section{B.Identifikasi Masalah}

Bagaimanakah self esteem pada anak remaja yang orang tuanya broken home di SMP Dharma Patra P.Brandan.

\section{Alasan kenapa penelitian ini dilakukan \\ Karena untuk mengetahui self esteem pada anak remaja yang orang tuanya broken home di SMP Dharma Patra P.Brandan}

\section{METODE PENELITIAN}

\section{Lokasi}

Penelitian ini dilaksanakandi SMP Dharma Patra Pangkalan Brandan yang berlokasi di Jln. Balikpapan, Puraka II, Pangkalan Brandan, Kec. Sei Lepan, Kab. Langkat. Pemilihan lokasi ini dikarenakan peneliti mendapat kemudahan dalam memasuki sekolah tersebut sehingga dapat mempermudah peneliti dalam memperoleh data. Dan sekolah ini belum pernah dilaksanakan penelitian yang sama dengan permasalahan yang sedang dibicarakan dalam penelitian ini.

Yang dimaksud dengan latar penelitian adalah kondisi ilmiah tentang objek penelitian baik di sekolah serta perangkat mampu letak geografisnya di SMP Dharma Patra P.Brandan

\section{A. Jenis Penelitian}

Suatu tujuan penelitian akan dapat dicapai jika penelitian tersebut dilaksanakan dengan menggunakan metode tertentu. Metode penelitian merupakan bagian yang sangat penting dari sesuatu penelitian, baik kualitatif maupun kuantitatif. Metode penelitian adalah prosedur atau cara mengumpulkan dan menganalisa data agar kesimpulan yang ditarik memenuhi persyaratan berpikir induktif. 
Dalam penelitian ini, penulis mendiskripsikan kasus pada anak remaja yang orang tuanya broken home. Oleh sebab itu, penulis melakukan pendekatan dengan menggunakan pendekatan kualitatif. Bogdan dan Taylor yang dikutip Moleong, menjelaskan penelitian kualitatif di definisikan kata-kata atau lisan orang-orang dan prilaku yang dapat diamati.

Ciri-ciri penelitian kualitatif antara lain:

1. Pengumpulan data harus dilakukan secara ilmiah.

2. Peneliti merupakan instrumen utama.

3. Hasil penelitian disajikan dalam bentuk deskriptif

4. Penelitian kualitatif lebih mementingkan proses

5. Penelitian kualitatif bertujuan untuk mengungkapkan makna yang terkandung dibalik prilaku manusia.

6. Peneliti harus hadir di lapangan

7. Perspektif yang digunakan adalah perspektif emik, yaitu menurut pendapat orang yang diamati informasi.

Pendekatan peneliti yang digunakan dalam penelitian ini adalah pendekatan kualitatif (Qualiatif research). Bogdan dan Taylor dalam Moleong mendefenisikan metodologi kualitatif sebagai prosedur peneliti yang menghasilkan data deskriptif berupa kata-kata tertulis atau lisan dari orang-orang dan perilaku yang dapat diamati. Pendekatan ini diarahkan pada latar dari individu tersebut secara holistik (utuh). Jadi dalam hal ini diarahkan pada latar dari individu atau organisasi ke dalam variabel atau hipotesis tapi perlu memandangnya sebagai bagian dari suatu keutuhan.

Menurut Nasution penelitian kualitatif adalah mengamati orang dalam lingkungan, berinteraksi dengan mereka dan menafsirkan pendapat mereka tentang dunia sekitar.

Pada dasarnya penelitian dengan wawancara bertujuan untuk mengetahui tentang suatu hal secara mendalam. Maka dalam penelitian ini, peneliti akan menggunakan wawancara remaja untuk mengungkapkan tentang studi kasus self esteem pada anak yang orang tuanya broken home. Pemilihan metode ini didasari pada fakta bahwa tema dalam penelitian ini termasuk unik dan merupakan perilaku menyimpang.

Metode ini penelitian kualitatif yang digunakan adalah metode fenomenologi. Istilah fenomenologi berasal dari dari bahasa Yunani, yaitu phainomenon (penampakan diri) dan logos (akal). Ilmu tentang penampakan berarti ilmu tentang apa yang menampakkan diri pada pengalaman subjek. Donny Gahrial Adian dalam buku Pengantar fenomenologi menyebutkan bahwa fenomenologi adalah sebuah studi atau anak remaja tentang fenomena-fenomena atau apa saja yang tampak. Dengan kata lain fenomena merupakan mendapatkan penjelasan tentang realitas yang tampak.

Alasan peneliti menggunakan wawancara ini karena ditempat penelitian dilakukan untuk mewawancarai ke anak remaja itu tentang bagaimana harga diri nya atau disebut self esteem terhadap orang tuanya. Fenomena ini yang melatar belakangi penelitian ini dilaksanakan.

\section{B. Subjek Objek Penelitian}

Menurut Suharsimi Arikunto bahwa subjek penelitian adalah benda, hal atau organisasi tempat data atau variabel penelitian yang dipermasalahkan melekat. Tidak ada satupun penelitian yang dapat dilakukan bahwa dilaksanakannya penelitian di karenakan adanya masalah yang harus dipecahkan, maksud dan tujuan penelitian adalah untuk memecahkan persoalan yang timbul tersebut. Hal ini dilakukan dengan jalan mengumpulkan data sebanyak-banyaknya dari informan.

Subjek yang diteliti dalam penelitian kualitatif ini disebut informan yang dijadikan teman bahkan konsultan untuk menggali informasi yang dibutuhkan peneliti. Spradly (dalam Salim dan Sahrum), menjelasakan bahwa informasi yang dipilih haruslah 
seseorang yang benar-benar memahami kultural atau situasi yang ingin diteliti untuk memberikan informasi kepada peneliti.

Dalam peneliti ini penulis mengambil satu orang sebagai bahan wawancara data adalah "Anak remaja sebagai subjek dari pelaksanaan wawancara di lingkungan sekolah".

\section{Data Primer}

Pada saat penelitian yang saya dikemukan sifat remaja ini selama disekolah remaja ini seperti biasa sama seperti temantemannya disekolah, tidak ada sifatnya yang mencurigakan. Menurut pendapat remaja ini, disaat di kelasnya bahwa dia orangnya cuek sama teman sebaya di kelasnya.

\section{E. Data Sekunder}

Menurut pendapat teman sebayanya, remaja ini pada saat jam pelajaran kurang mampu dalam pelajaran saat guru menjelasin. Dan menurut pendapat temannya, temannya ini memanfaatkan remaja ini disaat jam istirahat. Karena remaja ini suka memberi uang saku kepada temannya pada saat jam istirahat.

\section{F. Teknik Pengumpulan Data}

Adapun teknik pengumpulan data dalam penelitian kualitatif ini adalah:

1. Observasi

Observasi yaitu mengadakan pengamatan langsung ke lokasi penelitian tentang self esteem pada anak remaja di SMP Dharma Patra P.Brandan.

2. Interview

Interview yaitu mengadakan wawancara atau tanya jawab secara langsung mengenai self esteem pada anak remaja. Yang dimaksud dengan wawancara adalah percakapan dilakukan oleh dua pihak yaitu (pewawancara) dengan yang di wawancarai.

Subjek dalam wawancara ini adalah anak remaja. Cara yang digunakan dalam wawancara ini adalah bertanya langsung yang bersangkutan.
3. Penelitian Dokumentasi, yaitu setiap bahan tertulis ataupun berbentuk foto. Peneliti mengadakan studi dokumentasi untuk mencari keabsahan penelitian. Subjek dalam data dokumentasi ini adalah foto-foto siswa.

\section{G. Instrument Penelitian}

Instrument penelitian menurut Suharmi Arikunto merupakan alat bantu bagi peneliti dalam mengumpulkan data. Sedangkan menurut Arikunto dalam edisi sebelumnya adalah alat atau fasilitas yang digunakan oleh peneliti dalam mengumpulkan data agar pekerjaannya lebih mudah dan hasilnya lebih baik dalam arti lebih cermat, lengkap dan sistematis, sehingga mudah diolah.

Instrument yang digunakan oleh penelti dalam hal ini adalah instrumen pokok yang instrumen penunjang. Instrumen pokok adalah manusia itu sendiri sedangkan instrumen penunjang adalah pedoman observasi dan pedoman interview. Instrumen pengumpulan data yang digunakan dalam penelitian ini adalah berupa daftar wawancara yang disusun sendiri untuk mengetahui hubungan konseling keluarga dengan pembentukan karakter remaja.

\section{H. Teknik Analaisis Data}

Proses analisis data didalam penelitian kualitatif dilakukan secara terus menerus. Artinya, sejak awal dilakukannya pengumpulan data sampai dengan berakhirnya penelitan, seseorang peneliti tidak boleh melakukan pencatatan dan analisis data yang telah diperoleh dilapangan.

Teknik yang digunakan oleh penulis dalam menganalisisdata adalah teknik analisis data menurut Miles dan Huberman yang meliputi 3 tahap, yaitu:

1. Reduksi (penyederhanaan) data, yaitu memilih dan memilah serta mengelompokkan data yang sesuai / mendukung tujuan oenelitian yang telah ditetapkan.

2. Display (penyajian) data, merupakan kegiatan menyajikan data yang telah melalui proses penarikan kesimpulan dari tia-tiap tema yang telah ditemukan. 
3. Penarikan kesimpulan, yang dilakukan setelah seluruh data melalui tahap reduksi (penyederhanaan).

\section{Teknik Penjaminan Keabsahan Data}

Untuk menjamin keabsahan data, peneliti menggunakan teknik triangulasi,tringulasi yaitu wawancara dengan data pengamatan dan dokumen. Triangulasi adalah teknik pemeriksaan keabsahan data yang memanfaatkan sesuatu yang lain.

Ada dua cara yang digunakan peneliti dalam penguji kebenaran data yaitu:

1. Mengumpulkan data dengan tema yang sama melalui sumber yang berbedabeda.

2. Membandingkan data yang diperoleh ari hasil wawancara dengan hasil pengamatan.

\section{HASIL DAN PEMBAHASAN}

\section{HASIL PENELITIAN}

Berdasarkan hasil wawancara dengan guru kelas, siswa (pelaku broken home) serta dokumentasi di dapatkan data sebagai berikut:

\section{Deskripsi Subjek Penelitian}

"H" ( nama inisial ) merupakan anak laki-laki dari 2 bersaudara. "H" tinggal di sebuah rumah sewa yang sederhana bersama seorang adiknya. Dan ia merupakan siswa kelas VII di SMP Dharma Patra P.Brandan. Di sekolah dia anaknya baik, ramah, banyak bergaul dengan teman-temanya. Selain itu, penampilan yang sering memakai gelang karet di tangan kirinya. Dan ia sangat rapi di saat sekolah sama seperti teman-teman sebayanya, tapi pada saat jam pulang sekolah, ia mulai keluarin baju sekolah.

Saat ini "H" berusia 14 tahun telah duduk di kelas VII SMP. Memang secara akademis, ia tertinggal dengan teman-temannya yang lain karena ia sedikit merasa bahwa dirinya berbeda dengan temannya di kelas.
"H" merupakan pelaku broken home yang memiliki karakteristik baik secara fisik maupun nonfisik, karakteristik secara fisik dapat teramati dari perawakan. Sedangkan karakteristik non fisiknya meliputi tempramen, empati dan perilaku pelaku temannya.

"H" memiliki perawakan secara fisik sama tetapi ada sedikit berbeda dibandingkan dengan teman yang lainnya. Perawakan tubuhnya sedikit berbeda dengan yang pada umumnya yaitu badan tinggi, sedikit gemuk dari pada dibandingkan dengan temantemannya.

"H" juga bernampilan seperti urakan mulai cara berpakaiannya hingga gestur tubuhnya. Pada saat sampai di sekolah ia sering terlambat, sering melanggar peraturan tata tertib sekolah. Setelah sampai di sekolah, ia terlihat rapi dimana baju dimasukkan dan rambutnya disisir rapi tetapi pada saat jam pertama ataupun istirahat pasti bajunya sudah keluar. Pada saat jumpa sama guru dan ditegur sama guru untuk merapikan bajunya masukkan ke dalam celana sekolah, ia langsung masukin bajunya dengan rapi. Tetapi setelah guru menegur ia, lalu ia di keluarin lagi bajunya sampai seterusnya begitu saja pada saat berjumpa sama guru.

1. Secara nonfisik, "H" merupakan remaja yang memiliki sedikit temprament tinggi. Ia mudah tersinggung dengan perkataan, pandangan atau bahkan tindakan temannya yang tidak sesuai kehendaknya.

\section{PEMBAHASAN}

\section{Dampak Broken Home}

\section{a). Perkembangan Emosi}

Selain itu juga, si remaja ini dulunya pernah tinggal bersama nenek dan kakek kandungnya. Tiba-tiba dia tidak betah tinggal bareng sama nenek dan kakeknya kandungnya. Setelah itu ia pindah dirumah nenek pihak mamaknya, nenek tirinya dan kakek kandungnya. Saat ia tinggal bareng bersama 
nenek tiri dan kakek kandungnya, ternyata nenek tirinya kurang peduli sama dia dan adiknya. Nenek tirinya itu kalau tinggal bareng sama dia banyak aturan dirumahnya dan sangat pelit sama cucu-cucunya.

Ini dapat dilihat dari kutipan:

"nenek saya ini sedikit pelit kak sama kami berdua. Makanya kami tidak mau tinggal bareng mereka."

"semuanya lah kak tentang kehidupan sehari-hari kami saat dirumah."

"H" pada saat saya menanyakan tentang dirinya, ia sangat menyantai pada saat saya menyanyakan ke dia nya. Tapi pada saat ia berbicara bersama dia, ia pernah mengalami kejadiaan pada saat ia menceritakan emosi menjadi pemurung, pemalas (menjadi agresif) pada saat jam-jam pelajaran tertentu.

Selain itu juga si remaja ini dulunya pernah mengalami pada saat ia masih kecil atau masih kanak-kanak ia pernah disiksa nenek kandungnya maupun nenek tirinya.

Ini dapat dilihat dari kutipan:

"pada saat saya tinggal bareng nenek dan kakek saya dibuat saya seperti pembantu kak. Terus saya di pukuli sama nenek saya kak pada saat saya masih kecil. Maka dari situ saya tidak mau tinggal bareng sama mereka sampai saat ini." (W102052017,B81-B87)

b). Perkembangan Sosial Remaja

" $H$ " memiliki sifat yang seperti ini dengan tingkah laku sosial kelompok yang memungkinkan seseorang berpartisipasi secara efektif dalam kelompok atau masyarakat. Akan tetapi si remaja ini tidak memiliki sifat yang terdapat seperti ini dibawah ini :

a). Perceraian orang tua menyebabkan ketidak percayaan diri terhadap kemampuan dan kedudukannya, dia merasa rendah diri menjadi takut untuk keluar dan bergaul dengan temanteman.

b). Anak sulit menyesuaikan diri dengan lingkungan.

c). Dampak bagi remaja yang tidak mempunyai ayah berperilaku dengan salah satu cara yang ekstrim, mereka sangat menarik diri pasif dan minder kemungkinan yang kedua terlalu aktif, agresif dan genit. c). Perkembangan Kepribadian

"H" pada saat tinggal dirumah neneknya, ia sempat mengeluh kepada neneknya. Karena neneknya ini sangat susah mendengar pembicaraan perkataan dari cucunya. Pada saat saya menanyakan si remaja ini, mengatakan kalau ia dan adiknya memang kurang kasih sayang dari neneknya, baik dari nenek orang tua mama maupun orang tua bapaknya.

Pada saat saya menanyakan ke remaja ini, ia tidak pernah mengalami atau menjalani disalah satu point-point di dalam ciri-ciri seperti ini:

1. Berperilaku nakal

2. Mengalami depresi

3. Melakukan hubungan seksual secara aktif

4. Kecenderungan pada obat-obat terlarang

\section{Penyebab Broken Home}

a. Orang tua yang kurang memiliki rasa tanggung jawab

"H" kurangnya kasih sayang yang dilakukan oleh dimana ia akan terlibat memunculkan rasa egois di dalam dirinya baik di sekolah, teman-temannya, maupun disekolah. Meski sebagian orang tua yang mengalami broken home mengetahui apa yang seharusnya ia berikan kepada anaknya, namun karena ego terhadap pasangan ia menjadi enggan melakukannya.

b. Ketidak dewasaan Sikap Orang Tua

Ketidakdewasaan sikap orang tua salah satunya dilihat dari sikap egoisme dan egosentrisme. " $\mathrm{H}$ " bisa jadi akan membenci ayah, ibu, atau bahkan kedua orang tuanya saat terjadi broken home. Ia belum bisa memahami dan menerima apa yang sebenarnya terjadi. Sehingga ia akan menganggap semua yang terjadi adalah kesalahan salah satu atau kedua orang tuanya. Ia tidak mau memilih kalau misalnya salah satu orang tua mereka untuk memilih untuk tinggal bareng mereka. Ia memilih untuk hidup mandiri bersama adik kesayangan dianya.

Ini dapat dilihat dari kutipan: 
"saya tinggal bersama adik saya kak. Dan kami tinggal di rumah sewa kak. (menunduk kepala kebawah)." (W102052017,B54-B56)

"tidak enak atau tidak nyaman kak kalau saya dan adik saya tinggal bersama bapak atau saudara." (W102052017,B60-B61)

\section{c. Adanya Masalah Pendidikan}

Masalah pendidikan sering menjadi penyebab terjadinya broken home, " $\mathrm{H}$ " saat jam pelajaran ia sangat sulit belajar di kelas. Ada salah satu guru mengatakan, si " $\mathrm{H}$ " di sekolah nilainya sangat buruk dari pada temanteman sekelasnya. Dan itu sebabnya karena suasana rumah yang tidak lagi kondusif untuk belajar akibat sering adanya pertengkaran, atau karena tidak adanya support orang sekitar yang membuatnya merasa tidak ada yang harus dibanggakan sehingga tidak perlu susah payah untuk mengukit prestasi. Maka ia tentu saja berbeda dengan teman-teman yang berasal dari keluarga utuh yang cenderung memiliki motivasi lebih tinggi dari mereka.

\section{Harga Diri}

Harga diri adalah sesuatu yang lebih mendasar dari pada yang terkait dengan naik turunnya perubahan situasi. Bagi orang-orang dengan harga diri yang baik, naik turun perasaan mereka tentang diri mereka sendiri dapat menyebabkan fluktuasi sementara, tetapi itu hanya sampai batas waktu tertentu saja. Sebaliknya, bagi orang-orang yang orang tuanya broken home harga diri atau 'self steem', pasang surut ini secara drastis mempengaruhi cara mereka memandang diri mereka.

Harga diri si remaja ini tinggi karena cenderung bersikap positif dalam perilakunya, individu mampu melihat dirinya berharga, diterima dan diperlakukan baik oleh orang lain. Begitu pula dalam konteks perilaku prososial, harga diri diperlukan agar remaja mampu melakukan tindakan yang menuntut pengorbanan (ikhlas) untuk membantu orang lain sesuai dengan apa yang diharapkan.
Ini dapat dilihat dari kutipan:

"saya kepingin orang tua saya seperti dulu kak mengumpul bareng-bareng lagi. Tapi sepertinya itu semuanya tidak bisa tejadi terulang seperti itu lagi kak. (sambil menunduk kepala kebawah)." (W102052017,B178-B181)

"sedikit sih merasa minder kak. Tapi ya sudahlah kak mau kayak mana lagi kak." (W102052017,B186-B187)

Guru berpendapat perilaku kenakalan di kelasnya dalam wajar dan merupakan sesuatu yang normal dalam perkembangan siswa. Guru masih belum memahami karena si " $H$ " orangnya tertutup, jadi sedikit susah untuk mengetahui. Sehingga penelitian harus memberikan dan membimbing. Karena Perceraian orang tua membuat tempramen remaja terpengaruh, pengaruh yang tampak secara jelas dalam perkembangan emosi itu membuat anak menjadi pemurung, pemalas (menjadi agresif) yang ingin mencari perhatian orang tua / orang lain. Mencari jati diri dalam suasana rumah tangga yang tumpang dan kurang serasi. Remaja yang kebutuhannya kurang dipenuhi oleh orang tua, emosi marahnya akan mudah terpancing. Guru harus memahami arti dari harga diri remaja yang broken home, tindakan remaja yang berada di dalam kelas. Guru menyebutkan beberapa melakukan kenakalan secara berulang-ulang kepada siswa tertentu.

Berdasarkan pendapat tersebut, dapat disimpulkan bahwa guru di SMP Dharma Patra P.Brandan harus memahami lagi remaja ini dan arti harga diri remaja yang broken home.

\section{Dimensi Harga diri}

Dari hasil penelitian didapatkan data bentuk broken home yang paling sering muncul adalah optimis dan yakin terhadap masa depannya. Perilaku ini menunjukkan ke remaja bahwasanya harga diri remaja yang tinggi.

Dari berbagai macam permasalahan yang dihadapi remaja, pada masa remaja ini mereka berusaha untuk mencari identitas dirinya dan berusaha mencari status sebagai seorang yang berdiri sendiri tanpa bantuan orang tua. Proses 
pembentukan identitas diri memiliki kaitan erat dengan bagaimana remaja menilai atau mengevaluasi diri.

Dalam pembentukan identitas diri siswa yang memperoleh keberhasilan secara sukses, maka siswa remaja tersebut dapat memenuhi kebutuhan dasarnya. Dalam hal ini Glesser mengungkapkan bahwa sekolah

mungkin mengarahkan anak pada kegagalan karena sekolah lebih menunjukkan wujud kurang perhatian secara pribadi kepada individu, Glesser juga mengamati bahwa banyak anak-anak yang membutuhkan cinta dan harga diri yang semula tidak ditemukan oleh remaja dirumah dan tidak ditemukan juga di sekolah sehingga semakin meningkatkan identitas kegagalan.

" $\mathrm{H}$ " memiliki gangguan harga diri tinggi di gambarkan sebagai perasaan yang positif terhadap diri sendiri, termasuk cenderung lebih efektif, aktif dan asertif dalam menyesuaikan diri dengan tuntutan lingkungan. Cenderung mandiri dalam situasi yang menimbulkan konformitas dan percaya diri bahwa dirinya akan sukses sehingga cenderung untuk berpartisipasi dalam aktivitas yang mandiri. individu mempunyai keyakinan dan rasa percaya diri bahwa dirinya mempunyai kemampuan untuk menghadapi suatu kejadian sehingga kecemasannya hilang dan dapat menahan implikasi negatif dari hukum sosial.

Ini dapat dilihat dari kutipan:

"untuk benci tidak ada sih kak. Tapi untuk sakit hati pasti ada kak." (W102052017,B172-B173)

"yang buat sakit hati saya karena kurang perhatian dari orang tua saya kak." (W102052017,B175-B176)

Berdasarkan hasil penelitian di SMP Dharma Patra ditemukan bentuk harga diri remaja yang broken home yang bersifat tertutup. Perilaku tidak mau menunjukkan sifat ia dengan cara di depan guru-gurunya.

\section{PERNYATAAN TEORITIK SESUAI TEMUAN PENELITIAN}

Dalam penelitian yang berjudul Studi Kasus Self Esteem Pada Remaja Yang Orang Tuanya Broken Home Di SMP Dharma Patra Tahun Pelajaran 2017 / 2018

1. Penelitian melakukan pengamatan pada remaja seorang diri, sehingga beberapa kejadian tidak terdeteksi oleh peneliti.

2. Pengamatan hanya dapat dilakukan di tempat-tempat yang tidak terlalu terlihat oleh remaja agar remaja tidak merasa terganggu, hingga beberapa percakapan remaja tidak terdengar jelas.

3. Tidak terlaksanakan wawancara pada guru bimbingan dan konseling karena di kesibukan guru tersebut.

\section{KESIMPULAN DAN SARAN}

\section{A. Kesimpulan}

Berdasarkan hasil penelitian yang telah dijabarkan sebelumnya mengenai studi kasus self esteem pada remaja yang orang tuanya broken home di SMP Dharma Patra P.Brandan dapat disimpulkan sebagai berikut:

Guru masih belum memahami karena "T" orangnya tertutup, jadi sedikit susah untuk mengetahui. Sehingga penelitian harus memberikan dan membimbing padana kata dalam Bahasa Indonesia, yaitu harga diri.

1. Guru harus memahami arti dari harga diri remaja yang broken home, tindakan remaja yang berada di dalam kelas.

2. Guru menyebutkan beberapa melakukan kenakalan secara berulangulang kepada siswa tertentu.

\section{B. Saran}

Berdasarkan kesimpulan yang telah disusun, peneliti mencoba memberikan saran utuk mencegah terjadinya broken home, yaitu: 1. Guru

a. Guru perlu menambah wawasan mengenai harga diri remaja yang broken home dari internet, buku agar dapat mencegah dan mengatasi.

b. Guru diharapkan mampu mengenali karakteristik pelaku korban agar dapat 
yang ada atau dapat muncul sewaktuwaktu.

c. Mengadakan konseling bagi siswasiswa yang bermasalah, baik korban maupun pelaku

d. Memberikan pengetahuan bagi siswa untuk lebih asersif sehingga remaja tersebut akan tidak akan trauma atau frustasi lagi.

e. Guru perlu memberikan perhatian pelakuan khusus untuk remaja ini.

\section{Keluarga}

Untuk mengatasi diperlukan partisipasi keluarga agar dapat mengajarkan dan membimbing remaja untuk bersikap asersif dan memberikan teladan yang baik di rumah

\section{DAFTAR PUSTAKA}

Branden (2001). How To Raise Your Self

Esteem. Jakarta. Pustaka Delapratasa.

Coopersmith (1967). The Antecendents Of Self

Esteem. USA. W.H Freeman and

Company

Clemes B, Harris, Reynold. 1995. Bagaimana

Kita Meningkatkan Harga DiriAnak.

Diterjemahkan oleh A.A

Nugroho.Bandung: Bina Rupa Aksara.

Corey, Gerald. 2005. Teori dan Praktek

Konseling dan Psikoterapi.

Bandung:Rafika Aditama.

Miles dan Huberman. Bullies and Victims: A

Primer For Parents. National Association

Of School Psychologists Elsevier

Academic Press: California

Moleong. 1999. Metodologi Penelitian

Kualitaf. Bandung: Rosdakarya

Nasution. 2003. Hipotesis Dalam Penelitian.

Jakarta: Rineka Cipta

Santrock, John W. 2003. Adolescence

Perkembangan Remaja Edisi Keenam.
Jakarta : Erlangga.

Suharsimi Arikunto.2006. Prosedur Penelitian. Jakarta: Rineka Cipta

Syansu, Yusuf LN. 2005. Psikologi

Perkembangan Anak danRemaja. Bandung: Remaja Rosda Karya

Wilis Srisayekti1, David A. Setiady, Rasyid Bo Sanitioso2015. Harga-diri (Selfesteem) Terancam dan Perilaku Menghindar.Jurnal PSIKOLOGI. VOl 42, NO. 2, hal 141 156

http://dyan123.blogspot.co.id/2012/02/pengert ian-harga-diri-dan-faktor-yang.html/. diakses tanggal 04 Juni2016

http://thesis.binus.ac.id/eColls/eThesisDoc/mar ellpdf/. diakses tanggal 04 Juni 2016

https://cintalia.com/kehidupan/anakanak/dampak-broken-home-terhadap-anak. diakses tanggal 04 Juni 2016 